\title{
INSTITUTIONAL DETERMINANTS OF INNOVATIVE DEVELOPMENT IN THE ECONOMY OF THE XXI CENTURY
}

\author{
Vasyl Lagutin', Yuliya Yasko²
}

\begin{abstract}
The article analyzed the problem of institutional determinants of innovative development in the 21 st century, which is not yet sufficiently understood in a scientific sense. It is established that poor quality and inconsistency of institutions with macro- and microeconomic mechanisms exacerbates the problem of institutional determinants of providing innovative development in the economy of the 21st century. The subject of the research is the institutional determinants (a set of formal and informal rules and regulations, incentives and mechanisms) that determine the provision of innovative development. Economic development implies a progressive change in the institutional environment of the national innovation system. In the context of the above, it is proved that the peculiarities of the content of institutional determinants of innovative development in Ukraine are characterized by complication of interconnections and forms of manifestation, strengthening of transformational tendencies. It is determined that the effect of institutional determinants is manifested through the influence of three types of institutions: primary (basic) market institutions (protection of property rights and investments, observance of rights and obligations, fixed by the contract system, freedom competition); development institutes (regulatory environment, business climate, regulatory business opportunities, judicial independence); institutes of efficiency (developed human and social capital, effective legislative support, impartiality of judges, reliability of law enforcement agencies. The research methodology is based on the methods of a holistic systematic approach to institutional analysis, interconnections and the logic of institutional determinants of innovation development. It is crucial to build holistic logical constructs (based on a model of innovative behavior) that allow a full analysis of existing institutional relationships. The purpose of the research is to analyze the institutional determinants of innovation development in the economy of the 21st century, to evaluate possible directions for more effective innovation management. Regulation of scientific aspects of institutes and institutional determinants allowed to re-evaluate traditional problems of innovative development. The main conclusions of the research relate to the justification of the set of institutional determinants that ensure the effective interdependence of institutional and innovation dynamics. It is argued that the institutional determinants of innovative change cannot be considered outside the interconnections. It is determined that the most problematic issues of readiness for innovation are: a small proportion of firms that are able to perceive and implement innovative technologies, lack of sufficient resources, low interest in purchasing new technological products. It is established that the effective use of institutional determinants of innovative development is possible only on the basis of the formation and effective implementation of the mechanism for managing the institutional stimulation of relevant innovation changes. It has been shown that scientific clarification of institutional determinants is a prerequisite for a deeper analysis of the effective development of the national innovation system. Only effective institutions can provide the necessary opportunities for innovative development. In this context, there is a need to further expand the institutional research of the innovation system.
\end{abstract}

Key words: institutes, institutional determinants, institutional stimulation, innovations, innovative system, innovative development.

JEL Classification: E02, O12, O30

\footnotetext{
Corresponding author:

${ }^{1}$ Kyiv National University of Trade and Economics, Ukraine.

E-mail: v.lagutin@knute.edu.ua

ORCID: https://orcid.org/0000-0001-6626-4381

ResearcherID: N-7693-2016

${ }^{2}$ Kyiv National University of Trade and Economics, Ukraine.

E-mail: y.yasko@knute.edu.ua

ORCID: https://orcid.org/0000-0002-8756-4612

ResearcherID: B-9894-2019
} 


\section{Introduction}

The interconnection of institutional transformation and innovative development is evident that in various aspects is revealed in the economic literature: conceptual - A. Greif (2006), D. North (1990), J. Schumpeter (1942/2003); socioeconomic - D. Acemoglu, S. Johnson, J. Robinson (2004), W. Baumol (2002), D. Rodrik (2007); historical and economic - M. Kreuzer (2001); economic and technological - K. Schwab (2018), M. Guerrero, D. Urbano (2019), N. Carvalho, Z. Yordanova (2018), R. Malaquias, A. Albertin (2018); program-target UNCTAD (2018), World Economic Forum (2019).

The low quality of institutions and their inconsistency with macro- and microeconomic mechanisms exacerbates the problem of institutional determinants of innovative development in the 21st century economy. The problem of scientific identification of institutional determinants (causes and factors) of innovation development is relevant and significant today. First of all, it is about the relevance of the research of the content of institutional rules and mechanisms for ensuring their compliance, structural and essential characteristics of institutional constraints, as well as the forms of their evolution in the process of institutional management of the new information economy.

All of the above conditioned the relevance of the following scientific tasks of the research: theoretical and methodological assessment of the content of institutional determinants of innovative development, identification of features of the system of institutional determinants of information economy. The need to solve problems involved with the innovative development of the 21 st century economy will require the use of new stimulating institutional determinants in management theory and practice. These tasks determined the logic of submission of the material under study.

Based on a systematic understanding of the interconnection and interaction between institutional and information-network transformations, prospects are opened for developing important provisions of the institutional theory of innovative development, which allows to explain both traditional tendencies and patterns, and new, not actually studied, issues of improvement of economic institutions.

\section{Theoretical characteristics of institutional determinants of innovative development}

Institutionalism in this article is considered in a broad enough methodological sense, including all the main areas of modern neo-institutional theory in the context of a broad interpretation of various patterns of social (collective) forms of existence.

Institutional determinants will be understood to mean those factors (a set of rules and regulations, as well as mechanisms of implementation), by which the relations and interactions between entities of the innovation market are institutionally structured and the conditions for innovation development are provided. It is important not only to identify the relevant institutional determinants, but also to show: in what cases and how do they interact to maximize the positive effects? In order to the potential institutional determinants of innovative development to work, the respective institutions must be compatible in their content and form, and adequate organizations in the economy and public authorities should be capable of interaction (coordination).

Innovative development can only be achieved through effective institutions. Existing institutions are embedded in an economy that they simultaneously reflect and shape. Institutions should be embedded in relevant business practices. Higher quality institutions contribute to innovative development, while poor quality ones have a negative impact on this process.

Institutions arise on the basis of a complex interaction of economic and socio-political factors, endogenous and exogenous circumstances, determined by mental socio-cultural factors, beliefs and customs of a given society. It is obvious that economic institutions are closely intertwined with political, legal, social and ethical standards. Under these conditions, institutional theory cannot but be based on an integrated approach and analysis of the mutual penetration of these norms. In this respect, it is obvious that the influence of institutional determinants on the dynamics and perspectives of innovative development is largely determined by the specificity of civic culture and the level of development of human and social capital. A kind of stabilization framework for the innovative development of the national economy is the balance of the multi-level system of interests of economic entities.

The effect of institutional determinants is manifested through the influence of three types of institutions: primary (basic) market institutions (protection of property rights and investments, observance of rights and obligations fixed by the contract system, freedom of competition); development institutes (regulatory environment, business climate, normative business opportunities, judicial independence); institutes of efficiency (developed human and social capital, effective legislative support, impartiality of judges, reliability of law enforcement agencies). The proper functionality, reliability and efficiency of the creation and systematic functioning of these institutions are the necessary conditions for ensuring the innovation of the XXI century economy. Outside the holistic interaction of basic market institutes, development institutes and efficiency institutes, it is impossible to ensure innovative development in such perspectives in the 21 st century areas such as: artificial intelligence, automation of robotic processes, intelligent transport systems, blockchain, intellectual things (including the Internet of Things), quantum and cloud computing, 
nanotechnology, biotechnology, fintech technology, digital ecosystems, etc.

With regard to Ukraine, under the current conditions, the threats of innovative development are caused by the influence of a number of destructive determinants - both external (unfavorable geopolitical situation, currency and financial instability, excessive dependence on world commodity markets), and internal (high level of corruption, oligarchization of economy, shadowing, acute structural imbalances). Innovative development will be severely curtailed if there are no structural reforms adequate for fiscal and monetary policy.

If earlier it seemed that the tendency of low level of innovative development in the economy of Ukraine is temporary and will be overcome in the near future without much institutional effort, today it becomes more and more clear that the situation is much more complicated. A long-term trend is a violation of the natural mechanism of creative destruction (according to J. Schumpeter). This is, in our opinion, the main institutional reason for the lack of incentives for the Ukrainian business to innovate development.

\section{Model of innovative behavioral companies (formalization of tasks)}

Despite the large inertia, firms' response to technological and innovation challenges can generally be considered satisfactory. However, questions about the effectiveness of innovation institutions, the use of incentives to promote innovation, the volume and structure of funding remain. Is innovative development possible in the absence of a full-fledged innovation market and technology transfer in Ukraine, poor quality and insufficient institutional determinants of innovative development?

To answer these questions, at least in the first approximation, we formulate the simplest model of innovative behavior of a modern firm on the basis of adaptive management. Let $\mathrm{I}_{\mathrm{d} 1 \ldots} \mathrm{I}_{\mathrm{dn}}$ denote the institutional determinants (one of three types of stimulating, disincentive, neutral) that influence innovation $\left(I_{H}\right)$, which should be implemented at the basic level of impact $\left(i_{0}\right)$. These types of institutional determinants under specific socio-economic conditions are not alternative or mutually exclusive. In fact, the complex effect of institutional determinants of innovation development can often be explained only within the limits of all these interpretations.

The general statement of the control problem in this case involves the selection of the control object $-I_{H}$, the dynamics of which depend on managerial influence $-I_{d}$. After increasing the level of influence of the institutions $\left(i_{0}\right)$, for example, by $10 \mathrm{pp}$. $(0,1)$ institutional incentives for innovative development, all things being equal, are increasing at $\left(i_{0}+0,1\right) / i_{0}$ times. In this case, the external impact is determined by the amount of resources or investment costs that depend on the discount rate $-\delta$. Thus, the equation of operation of the control object will look like:

$$
I_{u(t)}=\delta\left(i_{0}+0,1\right) / i_{0} I_{d}
$$

where: $t-$ is a certain point in time.

Let as a result of strengthening of stimulating influence of institutional determinants firm increases production output by $(1+q)$ times. Then the investment costs can be offset by increasing the income from innovation. Suppose that revenue from innovation increases in proportion to output. In this case, the economic impact of the innovative activity $\left(Y_{j t}\right)$ will be:

$$
Y_{j t}=q I_{u(t)}\left(i_{0}+0,1\right) / i_{0}
$$

where: $I_{n}\left(i_{0}+0,1\right)$ - innovations that the firm would introduce in enhancing the incentive effect of institutional determinants and previous output; $j$ - kind of innovation.

Formulas (1) and (2) hold, first and foremost, for institutional determinants.

Thus, by expanding the use of innovative technologies and ensuring output growth, the firm thus creates the conditions for maximizing the economic impact of innovative development. Let this increase in economic effect also occur in proportion to the change in output. In this case, the task of maximizing the economic impact of innovative development will look like:

$$
\begin{aligned}
& \sum_{j=1}^{n} Y_{j t \rightarrow} \operatorname{max~за~умови~} \\
& \sum_{j=1}^{n} a_{k j} i_{j} \leq s_{k} k=1, \cdots, m, i j \geq 0, j=1, \cdots, n
\end{aligned}
$$

where: $a_{k j}$ - the amount of resources spent to implement j-type innovation; $s_{k}$ - given volumes of resources; $i_{j}$ - the impact of institutional determinants on achieving the proper effect of $j$-type innovation.

If $i_{j}$ (incentive and neutral determinants) is negative, this task is solvable and the total effect of implementation of innovation can be expressed by the amount of resources expended.

Of course, the assumption of direct proportion dependence the effect on innovation and output is simplification. The effect of implementing each type of innovation is calculated on the basis of its own compensation base. Generally, their values are nonlinearly related to production. But in substantiating the conceptual scheme of our model we will proceed from the fact that the proportions between the studied indicators are constant and do not change with the implementation of this or that type of innovation.

\section{Specificity of institutional determinants of innovative development in Ukraine}

In the 1990s, primary (basic) market institutes and organizations were formed in Ukraine: private property, entrepreneurship, investment institute, infrastructure 
institutes (banks, exchanges), institute of business reputation, self-regulatory organizations. It is another matter that their content immediately turned perverted, and since the early 2000s all these basic market institutes have started to work for the interests of oligarchs and corrupt bureaucracy.

For development institutions, the costs of their formation and engagement will not be excessive if the benefits of operating these institutions outweigh the costs associated with their underperformance. In the context of the above, it can be said that the process of formation of innovative development institutes in Ukraine can be accelerated by identifying and supporting groups of economic entities that are in demand for these new institutions.

In the 21 st century, there is a larger and more complex task of establishing efficiency institutes. Efficiency institutes provide an opportunity to maintain the necessary institutional environment to ensure a higher level of innovative development. These tasks in Ukraine are still being addressed in a far ineffective manner with the mass of institutional distortions and strains. As a result, a true institutional archaic with its administrative and market principles was formed. Formation of positive innovative expectations in Ukraine is fraught with many difficulties. Thus, the role of opportunism in the economic behavior of firms, the bureaucratic and corruptive constraints of innovation is too important.

So far, the institutes formed in Ukraine do not induce effective innovative development, and the organizations formed on their basis have no motivation to create more stimulating economic rules. The performance of institutional determinants of innovative development in terms of underdeveloped institutions is worsening.

The quality of the institutional determinants of innovative development can be assessed by comparing the institutional components of international rankings.

Consider as an example the Global Innovation Index, which is one of the most famous indices in the world. On this basis, a comparative assessment of a number of institutional determinants of innovative development is carried out: political position, regulatory and business environment, level of trade and competition, business experience, etc.

In the 2018 Global Innovation Index, jointly prepared by Cornell University, the INSEAD Business School and the World Intellectual Property Organization, Ukraine ranked 43rd in 2018 (50th in 2017), ahead of the Russian Federation was 46th, Moldova was 48th, Kazakhstan was 74 th, Belarus was 86th (The Global Innovation Index, 2017). The basis of Ukraine's innovative competitiveness is human capital and research, as well as the knowledge and results of scientific research. At the same time, the ranking of Ukraine is low according to the subindex "Innovative capacity" in 2018, it is 58th place, and the subindex "Implementation of ICT" is 77 th place (The Global Innovation Index, 2017).
Ukraine has a rather low ranking of institutions and the institutional environment of innovation in the global space. In 2018, Ukraine ranked 107th in the Institution sub-index (2017 - 101), including in terms of the political environment - 122nd (122nd place in 2017 ), regulatory - 78th ( $82 \mathrm{nd}$ in 2017), as of business environment - 100th (78th place in 2017). Market indicators of Ukraine are estimated at 42.7 points, which corresponds to 89th place in the rating (81st place in 2017 ), incl. on loans -84 th place, investments -115 th, level of trade and competition - 45th. According to business experience, Ukraine took 46th place (in terms of the number of intellectual workers it was 41 st place, innovation relations - 63rd, perception of knowledge 75th) (The Global Competitiveness Report, 2016-2018).

In the 2018 Global Competitiveness Index, Ukraine ranks 103rd in terms efficiency of legislative support in dispute resolution, 107th in the effectiveness of legislative support in appealing against decisions, 107 th in social capital, 109th in corruption coverage, organized crime -111 th place, protection of intellectual property rights -114 th place, government orientation for the future - 115th place, independence of judges -117 th place, auditing and reporting standards 120 th place, property right -129 th place (The Global Competitiveness Report, 2016-2018).

The indicators of such institutional determinants are low: the legal system and protection of property rights, communications and entrepreneurship, market and regulatory opportunities, the independence of the judiciary, the reliability of law enforcement, and the impartiality of judges. The lack of a proper institutional environment in Ukraine can be considered as one of the most serious barriers to innovative progress.

An acute problem is the lack of sufficient resources to fund innovation and their inefficient structure. If in 2016 the volume of financing of innovative activity in the economy of Ukraine amounted to 23.2 bln UAH ( $4.6 \%$ of gross value added in industry), it was smaller in other years. The only exception was 2015 with $13.8 \mathrm{bln}$ UAH (3.5\%) and 2011 with 14.3 bln UAH (4.8\%). The volume of financing for innovation activity in 2017 was very small - only 9.1 bln UAH (1.4\%), $2014-7.4$ bln UAH (2.4\%), 2013 - 9.6 bln UAH (3.2\%), 2012 11.5 bln UAH (3.7\%) (UkrISTEI, 2019).

An unfavorable factor for innovative development is the almost absolute predominance in the sources of financing innovative costs in the industry of Ukraine of the own funds of enterprises: 2012 - 63.9\%, $2013-$ $72.9 \%, 2014-85.0 \%, 2015$ - up to $97.2 \%, 2016-94.9 \%$, 2017 - 84.5\%. The underdeveloped banking system and stock market institutions cause for a very low share of loans and funds domestic and foreign investors in financing innovation: $2012-0.2 \%$ and $21.0 \%, 2013-$ $1.6 \%$ and $6.6 \%, 2014-0.1 \%$ and $7.3 \%, 2015-0.3 \%$ and $0.8 \%, 2016-0.4 \%$ and $2.7 \%, 2017-1.0 \%$ and $6.5 \%$ (UkrISTEI, 2019). 


\section{Institutional stimulation of innovative development (managerial aspect)}

Institutional stimulation of innovation is of paramount importance today. This means that adaptive management orientation must be combined with a gradual transition to active innovation management. It is important to base non-discretionary rules based on institutional management of innovative development: their development, use for influencing innovative behavior, management of these rules.

The modern mechanism for managing innovative development is based on the connection and interconnection between state regulation, innovative business and its institutional environment (institutional determinants) in the field of modern technologies of Industry 4.0. The content and logic of managing the institutional stimulation of innovative development is dictated by the specific economic situation of the firm.

Institutional management of innovation development is based on human capital, intellectual assets, the activities of innovator workers, research programs, financial support for innovation, investment growth, effective communication and entrepreneurship. All this enhances the innovative potential of the company.

The most problematic issues of readiness for innovation are: a small proportion of firms that are able to adopt and implement innovative technologies, lack of sufficient resources, low interest in purchasing new technological products. Innovative development is inseparable from enhancing the dynamism of a firm that applies self-organization principles based on its attractiveness to investors. The innovative development management system is designed to ensure that the goal is met to the fullest extent possible and to maximize the use of the incentive potential of the existing institutional determinants. In this regard, the three main management units can be considered: opportunities (innovation potential), innovation activity of the firm, the result of innovative development.

There are two ways of managing innovation development modes: mode of fast development and mode of slow development. The most difficult of all aspects of innovative development regimes is the mode of fast development, especially in the context of increasing uncertainty in the making and decision making. The mode of slow innovation development is usually one of the stages of implementation of crisis management. Mode of slow development is characteristic of the limited resources that a firm is able to allocate to support innovative development.

Increasing investment is necessary to ensure innovative development. A proper investment effect can only be achieved if effective institutions are in place. By analyzing the external institutional environment constantly, firms concentrate resources and investments on the most useful and profitable areas of innovative development. Without reliable institutions for innovative development, economic mechanisms for attracting investment will not work. Going beyond these limits with existing institutional determinants will only discourage innovative development.

The paradox of the situation often lies in the fact that a significant increase in investment can, in our view, significantly increase the risk of destabilization of existing institutions, which are not able to ensure the proper effectiveness of innovative activity. When development and efficiency institutes are in their infancy, they cannot give proper effect as institutional determinants of investment in innovative technologies.

It is considered that the resources of internal institutional sectors should become a real and adequate source of investment resources formation. Improving the quality of financial market institutions is required to put this innovative development factor into practice. In the current context, the lack of institutions of capital inflows and securitization discourages investment and innovation development. Financial institutional determinants must be able to fulfill their functions of effectively redistributing resources and risks to innovation.

In practice, only those innovations that will be realistically capitalized and promising in terms of winning a better competitive place in the market make sense. The firm must effectively perceive market changes, responding to them faster and more accurately. This will be facilitated, in particular, by the online capabilities of networking technologies, making new market information available anywhere and in real time.

The system of institutional determinants of innovative development adequate to the new conditions can be formed only on the basis of effective management. Innovative modernization will be the result of successful development management.

\section{Conclusions}

The analysis makes the following conclusions. The basis of innovative development is a viable institutional system that delivers innovation when appropriate institutional determinants are in place. In the case of unsatisfactory institutional determinants, the main parameters of innovation activity remain low. When determining the effectiveness of institutional determinants of innovation development, it is correct to compare the quality of institutions with the effect obtained (result). The complex effective use of institutional determinants of innovative development is possible only on the basis of the formation and effective implementation of the mechanism for managing the institutional stimulation of relevant innovation changes.

In discussing the innovative challenges facing firms in the 21 st century, one should rethink the traditional role of the institutional environment, taking into account 
the contemporary characteristics of the institutional dynamics of the world's leading countries. It is on this basis that the scale and versatility of innovation, which is a feature of Industry 4.0, will be ensured. Even today, and even more so in the future, innovations will have no socio-economic sense outside the information network. Any innovation should "enter" into network structures, become an element of the interactive network.
The identification and use of institutional determinants of innovative development is often very difficult. To overcome them, there is a need for a coherent management approach that would ensure the efficiency of the operating, financial and innovationinvestment processes of firms as elements of the socioeconomic system. In this case, additional research is required.

\section{References:}

Acemoglu, D., Johnson, S., \& Robinson, J. (2004). Institutionals as the Fundamental Cause of Long-Run Growth. In: Aghion Ph., Durlauf St. (eds.). Handbook of Economic Growth. North Holland, pp. 386-472.

Baumol, W. J. (2002). The free-market innovation machine: Analyzing the growth miracle of capitalism. Princeton University Press, $336 \mathrm{p}$.

Carvalho, N., \& Yordanova, Z. (2018). Why say no to innovation? Evidence from industrial SMEs in European Union. Journal of Technology Management and Innovation. Vol. 13, No 2, pp. 43-56.

Greif, A. (2006). Institutions and the path to the modern economy. New York: Cambridge University Press, 526 p. Guerrero, M., \& Urbano, D. (2019). Effectiveness of technology transfer policies and legislation in fostering entrepreneurial innovations across continents: an overview. The Journal of Technology Transfer. Vol. 44, No 5, pp. 1347-1366.

Kreuzer, M. (2001). Institutions and innovation: Voters, parties, and interest groups in the consolidation of democracy - France and Germany, 1870-1939. Ann Arbor: University of Michigan Press, 224 p.

Malaquias, R., \& Albertin, A. (2018). The Value of Being Innovative in Information Technology. Journal of Technology Management and Innovation. Vol. 13, No 1, pp. 3-10.

North, D. C. (1990). Institutions, institutional change, and economic performance. New York: Cambridge University Press, $152 \mathrm{p}$.

Rodrik, D. (2007). One economics, many recipes: Globalization, institutions, and economic growth. Princeton University Press, $280 \mathrm{p}$.

Schumpeter, J. A. (1942/2003). Capitalism, socialism and democracy. London and New York: Stockholm University, $460 \mathrm{p}$.

Schwab, K. (2018). Shaping The Fourth Industrial Revolution. World Economic Forum. Geneva, 274 p.

The Global Innovation Index (2017). URL: https://www.globalinnovationindex.org/gii-2017-report; The Global Innovation Index 2018. URL: https: / /www.globalinnovationindex.org/gii-2018-report (accessed April, 7, 2019). The Global Competitiveness Report. World Economic Forum (2016-2018). URL: http://www3.weforum.org/ docs/WEF_TheGlobalCompetitivenessReport (accessed April, 7, 2019).

UkrINTEI (2019). Stan innovacijnoji dijaljnosti ta dijaljnosti u sferi transferu tekhnologhij v Ukrajini u 2018 roci: analitychna dovidka. Kyiv: UkrINTEI, 80 p.

UNCTAD (2018). World investment report 2018. Investment and new industrial policies. United Nations publications, $213 \mathrm{p}$. 